\title{
Review
}

\section{Drug Delivery with Polymeric Nanocarriers-Cellular Uptake Mechanisms}

\author{
Levi Collin Nelemans $[$ and Leonid Gurevich * \\ Department of Materials and Production, Aalborg University, 9220 Aalborg, Denmark; levinelemans@gmail.com \\ * Correspondence: lg@mp.aau.dk
}

Received: 20 December 2019; Accepted: 9 January 2020; Published: 13 January 2020

\begin{abstract}
Nanocarrier-based systems hold a promise to become "Dr. Ehrlich's Magic Bullet" capable of delivering drugs, proteins and genetic materials intact to a specific location in an organism down to subcellular level. The key question, however, how a nanocarrier is internalized by cells and how its intracellular trafficking and the fate in the cell can be controlled remains yet to be answered. In this review we survey drug delivery systems based on various polymeric nanocarriers, their uptake mechanisms, as well as the experimental techniques and common pathway inhibitors applied for internalization studies. While energy-dependent endocytosis is observed as the main uptake pathway, the integrity of a drug-loaded nanocarrier upon its internalization appears to be a seldomly addressed problem that can drastically affect the uptake kinetics and toxicity of the system in vitro and in vivo.
\end{abstract}

Keywords: drug delivery systems; endocytosis; polymeric micelles; amphiphilic block copolymers; nanoparticles; drug release

\section{Introduction}

Nanocarriers have great potential as drug delivery systems (DDS). They enhance the bioavailability of drugs, extent circulation times and can accumulate in compromised tissue via an effect known as enhanced permeability and retention (EPR) [1-3]. In the past few years, the amount of nanocarriers in clinical trials has tripled [4]. Specifically, polymeric micelles have received growing attention due to their small size, simplicity and ability to transport hydrophobic drugs inside their core $[3,5,6]$. Furthermore, improved polymerization techniques lead to well-defined structures, narrow molecular weight distributions and tunable properties [1]. Polymeric micelles are composed of amphiphilic block copolymers (ABCs) containing hydrophobic and hydrophilic blocks [7]. When these ABCs are dissolved (in aqueous solution) at a concentration above their critical aggregation concentration (CAC), they will self-assemble into aggregates with a hydrophobic core and hydrophilic corona (Figure 1). Due to their low CAC and further stabilization due to a hydrophobic load, these polymeric micelles are relatively stable at working concentrations in the blood [1]. 


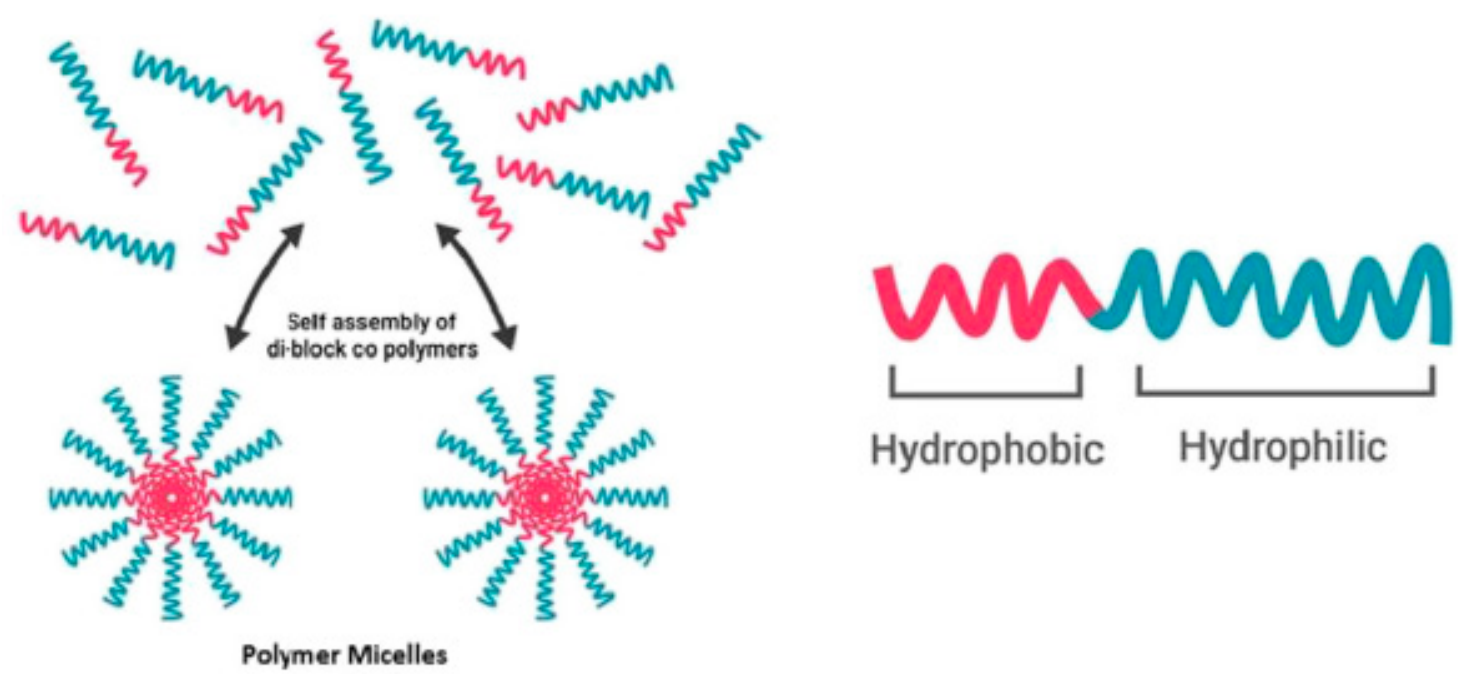

Figure 1. Above the critical aggregation concentration, amphiphilic block copolymers self-assemble into a micellular structure (adapted from Reference [8] with permission from Elsevier).

The hydrophobic block will influence the stability and drug release characteristics, while the corona influences the pharmacokinetic properties in vivo and can potentially be further modified (e.g., for active targeting, facilitated cell penetration and so forth. $[1,9,10])$. Poly(ethylene glycol/oxide) (PEG/PEO) is most commonly used as the hydrophilic block, while the hydrophobic block varies widely [11,12]. Poly(N-(2-hydroxypropyl)methacrylamide) (PHPMA) is a hydrophilic polymer that is a worthy competitor of PEG; it is biocompatible, non-toxic, non-charged and non-immunogenic [13]. Furthermore, the polymer contains hydroxyl moieties, which can be functionalized with targeting ligands, used for drug conjugation or facilitate other modifications that could potentially lead to the development of new micelle-based technologies [1]. Poly(N-vinyl-2-pyrrolidone) (PVP) has also been used to create polymeric micelles and potentially has the ability to cross membranes via biologically independent mechanisms, based on size $[1,9,14]$. It can be further modified with acrylic acid allowing a broad range of further modifications [15]. A relatively new class of polymer being used as DDS is poly(2-oxazoline) (POz). It is very versatile, and many different monomers can be produced with a wide variety of properties $[1,16]$. An example is poly(2-ethyl-2-oxazoline) (PEOz) which is used in polymeric micelles [17].

Polymeric micelles are intensively studied, and many excellent review articles give an overview of the composition of different polymeric micelles [2,7,18-22]. However, often only the cytotoxicity of these nanocarriers and their cargo are investigated, while the specific nanocarrier uptake and intercellular trafficking are mostly overlooked. The interaction between polymeric micelles and cell membranes is largely unknown and the fate of these polymeric micelles and their cargo after internalization remains to be clarified [6]. One of the concerns after internalization could be autophagy, which can greatly reduce the therapeutic effects of the drug $[6,23]$. Therefore, a better understanding of polymeric micelle uptake and drug release is crucial for creating an optimal DDS [24].

However, the uptake mechanisms of polymeric micelles are hard to generalize, since not only the physicochemical characteristics of the polymeric micelles but also the actual encapsulated drug and cell type play a crucial role in the uptake $[25,26]$. In this review, the uptake mechanisms for different polymeric nanocarriers are discussed, alongside with various experimental techniques commonly applied for discerning specific uptake mechanisms.

\section{Endocytosis as the Main Uptake Mechanism in Cells}

Nutrients and other substances are mainly taken up by cells in a cellular process called endocytosis. Most nanocarriers are also thought to be taken up by this process. Traditionally, endocytosis can be divided into phagocytosis (uptake of large particles) and pinocytosis (uptake of fluids and solutes) 
(Figure 2). The latter can be further divided into macropinocytosis, clathrin-mediated endocytosis, caveolae-mediated endocytosis and clathrin- and caveolae-independent endocytosis. While these different uptake mechanisms have been extensively studied, they are still not fully understood. This is caused by the complexity of the processes, overlap of proteins involved in different mechanisms and the lack of mechanism-specific inhibitors [24].

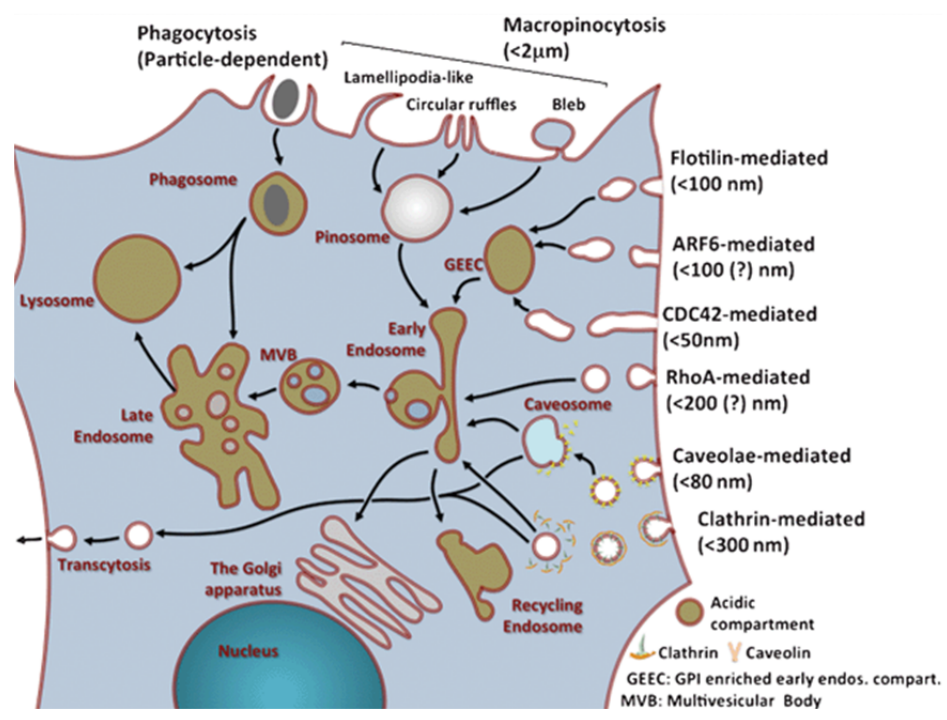

Figure 2. Overview of uptake and internal trafficking via various endocytic pathways in a typical eukaryotic cell, with an estimated maximum uptake size for different pinocytosis mechanisms (reproduced from Reference [24] with permission from The Royal Society of Chemistry).

\subsection{Phagocytosis}

Phagocytosis is only performed by a few specialized cells named phagocytes (macrophages, neutrophils, dendritic cells, etc.). Some other cells types, such as fibroblasts, epithelial and endothelial cells, might also display phagocytic behavior but to a much lesser extent [27,28]. The main task of phagocytes is to kill and remove pathogens, dead cells and cell debris. Phagocytosis is triggered via recognition of the particle via receptors on the phagocyte, which leads to recruitment of actin around the particle, followed by engulfment (Figure 3A) [29]. The created phagosomes are believed to eventually fuse with lysosomes, creating phagolysosomes. The acidic and enzyme-rich environment in these phagolysosomes will (promote) break down of any biodegradable nanocarriers or sensitive drugs [27]. Coating of the particle with immunoglobulins, complement proteins and other molecules enhancing phagocytosis (opsonins) — the so-called opsonization-will promote phagocytic uptake. Therefore, it is essential for a DDS to avoid opsonization, which will lead to subsequent clearing by the reticuloendothelial system (RES) from the bloodstream (Figure 4) [27].

The maximum size of nanocarriers that can be taken up via phagocytosis seems to be determined by the phagocyte's cell volume. However, the particle shape might also influence the uptake. Champion et al. created polystyrene particles of different shapes and sizes and showed that the curvature of the particle at the initial point of contact determined the ability of the phagocyte to engulf the particle [30,31]. 


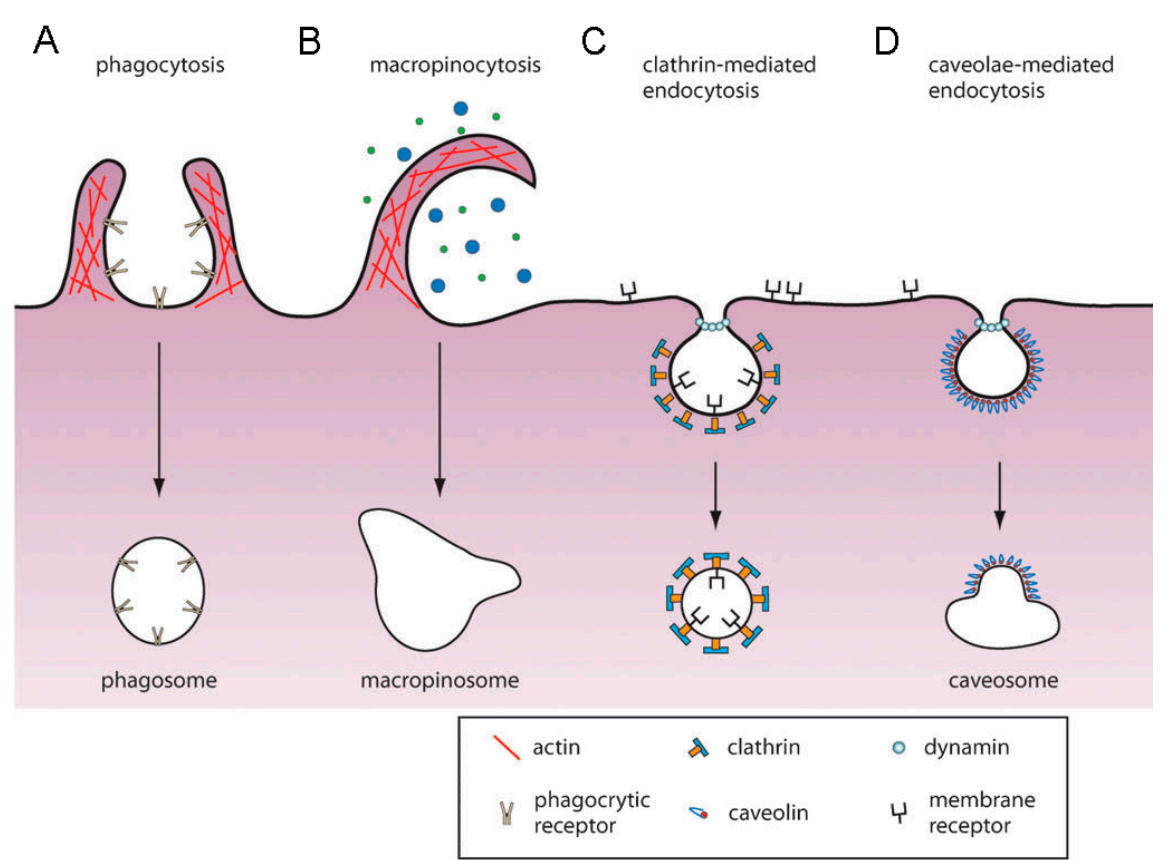

Figure 3. Uptake mechanisms of mammalian cells: (A) phagocytosis, (B) macropinocytosis, (C) clathrin-mediated endocytosis and (D) caveolae-mediated endocytosis. See text for more details. (Reproduced from Reference [32] with permission from The Royal Society of Chemistry).

\subsection{Pinocytosis}

In contrast to phagocytosis, pinocytosis can be found in nearly all cells. Of the different pinocytosis mechanisms, clathrin-mediated endocytosis (CME) is the most studied to date and was first discovered in 1964 by Roth and Porter [24,33]. CME is mainly responsible for the uptake of essential nutrients, down regulation of cell signaling and maintaining cellular homeostasis (Figure 3C) [29]. In short, CME involves engulfment and upconcentration of transmembrane receptors bound to ligands on the plasma membrane. On the cytosolic side of the membrane, a coated pit is formed by cytosolic proteins, with clathrin as main unit [34]. These clathrin-coated pits are then pinched off the membrane by a small GTPase known as dynamin, forming clathrin-coated vesicles (CCV). Once the CCV is detached from the membrane, the coat will disassemble, and the vesicle will undergo further intracellular trafficking. Nanocarriers that enter the cell through CME are mostly targeted to degradative lysosomes. First, the cargo will be transported to early endosomes $(\mathrm{pH} \sim 6)$, which will mature into late endosomes $(\mathrm{pH} \sim 5)$. These late endosomes will fuse with prelysosomal vesicles to form lysosomes that have an acidic $(\mathrm{pH} \sim$ 4-5) and enzyme-rich environment (containing e.g., hydrolases) for degradation [27,35]. This pathway could be utilized to release the drug via biodegradation of the carriers only when the nanocarriers contain drugs that are stable under these harsh conditions. Otherwise, endosome escape strategies could be explored to optimize drug delivery [35-37].

Caveolae-mediated endocytosis (CvME) is another major uptake route responsible for biological functions, such as cell signaling, lipid regulation and vesicular transport (Figure 3D). The dimeric protein caveolin-1 (and caveolin-3 in muscle cells) is responsible for the specific flask shape of the vesicles and can be found as a striated coat on the cytosolic surface of the membrane [34]. As in CME, dynamin is responsible for scissoring of the vesicle from the membrane. These vesicles seem to fuse with caveosomes, thereby bypassing lysosomes. Therefore, CvME could be an interesting pathway for DDS to avoid lysosomal degradation [38].

Macropinocytosis is an endocytic process that entails engulfment of a large volume of the extra cellular milieu and is not directly driven by cargo (Figure 3B). This uptake is associated with membrane ruffling and can be induced by growth factors, bacteria, viruses and necrotic cells [24]. Some of these membrane protrusions can fall back onto the membrane and fuse with it, creating macropinosomes. 
These membrane protrusions are actin-driven and induced by the Rho-family GTPases [17]. Why only some protrusions result in micropinocytosis and how this process is regulated, is yet unknown. Macropinosomes are believed to fuse with lysosomal compartments, leading to degradation of the contents [27].

Cells that are depleted of CME and CvME still show some form of endocytosis. All these different uptake mechanisms are grouped together as clathrin-and caveolae-independent endocytosis. The uptake seems to be cholesterol dependent and involve lipid raft sorting on the membrane, however most pathways are still poorly understood [29]. A noteworthy example is the uptake of interleukin-2 receptors (IL-2), which seems to be clathrin- and caveolae-independent [34].

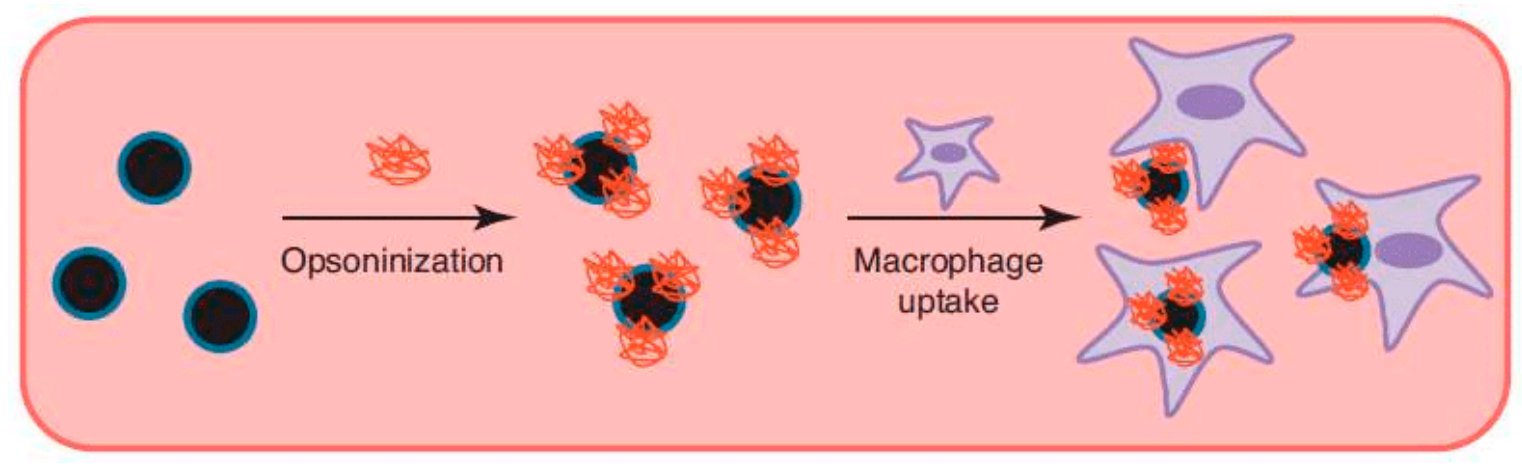

Figure 4. Opsonization of nanoparticles in the bloodstream will lead to rapid clearing by the reticuloendothelial system via phagocytic uptake of the particles by macrophages (reproduced from Reference [39] with permission from Elsevier).

\subsection{Elucidating Endocytic Pathways of Nanocarriers}

A common way to analyze the uptake mechanisms of nanocarriers is by using endocytic inhibitors. When inhibition of a certain pathway drastically lowers the uptake of a nanocarrier, it is assumed to be responsible for nanocarrier uptake. However, most inhibitors are not specific to one endocytic pathway and may induce other side effects [5]. Furthermore, by inhibiting one specific mechanism, a secondary uptake mechanism might compensate, while it may not have been originally active [40]. These limitations to endocytic inhibitors are often overlooked, therefore the use of multiple inhibitors is recommended to verify the results. Table 1 gives an overview of some of the most used inhibitors with their main mechanism(s) and limitations.

Another, more precise approach for elucidating a specific uptake mechanism is the use of siRNAs. siRNAs can be used to reversibly inhibit the production of certain key proteins in endocytosis (e.g., clathrin, caveolin), which should reduce off-target effects [40-42]. Furthermore, it gives a better understanding of the involvement of certain proteins in endocytic pathways [43]. 
Table 1. Overview of commonly used endocytic inhibitors, their effects and limitations [40,44-46].

\begin{tabular}{|c|c|c|c|c|}
\hline Agent & Mechanism Affected ${ }^{1}$ & Effect & Limitation & Ref. \\
\hline Low temp (4 degrees) & $\begin{array}{l}\text { All energy dependent } \\
\text { processes }\end{array}$ & $\begin{array}{l}\text { Slows down/inhibits all energy } \\
\text { dependent processes }\end{array}$ & $\begin{array}{l}\text { Low temperature may influence } \\
\text { fluidity of cell membrane }\end{array}$ & {$[47,48]$} \\
\hline Sodium azide & $\begin{array}{l}\text { All energy dependent } \\
\text { processes }\end{array}$ & Inhibits respiratory system of cells & Toxic at higher concentrations & {$[49,50]$} \\
\hline Chlorpromazine & CME & $\begin{array}{l}\text { Translocates clathrin and AP2 from the } \\
\text { cell surface to intracellular endosomes }\end{array}$ & $\begin{array}{l}\text { Not efficient in all cell lines, might } \\
\text { interfere with the biogenesis of } \\
\text { intracellular vesicles }\end{array}$ & $\begin{array}{l}{[51-53][54]} \\
(\text { pp. 19-20) }\end{array}$ \\
\hline Cytosol acidification & $\mathrm{CME}$ & $\begin{array}{l}\text { Inhibits the budding-off of clathrin- } \\
\text { coated pits from the membrane }\end{array}$ & $\begin{array}{l}\text { Interferes with macropinocytosis and } \\
\text { the actin cytoskeleton }\end{array}$ & [54] (p. 19) \\
\hline Hypertonic sucrose & $\mathrm{CME}$ & $\begin{array}{c}\text { Removes plasma membrane-associated } \\
\text { clathrin lattices }\end{array}$ & $\begin{array}{l}\text { Nonspecific, interferes with fluid } \\
\text { phase macropinocytosis }\end{array}$ & $\begin{array}{l}{[54](\text { pp. } 17-18)} \\
{[55,56]}\end{array}$ \\
\hline Monodansylcadaverine & $\mathrm{CME}$ & Stabilizes clathrin-coated pits & $\begin{array}{c}\text { Induces global changes in actin } \\
\text { dynamics }\end{array}$ & [54] (p. 20) \\
\hline Phenylarsine oxide & CME & $\begin{array}{l}\text { Mechanisms unknown, possibly a } \\
\text { tyrosine phosphate inhibitor }\end{array}$ & $\begin{array}{l}\text { Also inhibits micropinocytosis and is } \\
\text { toxic at higher concentrations }\end{array}$ & {$[57,58]$} \\
\hline Potassium depletion & CME & $\begin{array}{c}\text { Removes plasma membrane-associated } \\
\text { clathrin lattices }\end{array}$ & Nonspecific; affects actin cytoskeleton & [54] (p. 18) [59] \\
\hline Dynasore & CME, CvME & Inhibitor of dynamin (small GTPase) & $\begin{array}{l}\text { Has other off-target effects, including } \\
\text { inhibition of membrane ruffling }\end{array}$ & {$[60,61]$} \\
\hline Genistein & CvME & $\begin{array}{l}\text { Inhibitor of several tyrosine kinases, } \\
\text { causes disruption of the actin network }\end{array}$ & Affects several uptake processes & {$[62,63]$} \\
\hline Okadaic acid & CvME & $\begin{array}{l}\text { Phosphatase inhibitor, stimulates } \\
\text { trafficking and internalization of caveolae }\end{array}$ & Nonspecific, off-target effects & [64] \\
\hline \multicolumn{5}{|c|}{ Cholesterol inhibitors } \\
\hline Filipin & CvME, Lipid raft & Binds to cholesterol in the membrane & $\begin{array}{c}\text { Unstable and toxic, cholesterol } \\
\text { influences other endocytic pathways } \\
\text { besides CvME }\end{array}$ & $\begin{array}{c}{[54](\text { pp. 23-24) }} \\
{[65,66]}\end{array}$ \\
\hline
\end{tabular}


Table 1. Cont.

\begin{tabular}{|c|c|c|c|c|}
\hline Agent & Mechanism Affected ${ }^{1}$ & Effect & Limitation & Ref. \\
\hline Statins & CvME, Lipid raft & $\begin{array}{c}\text { Lowering of cholesterol formation by } \\
\text { inhibiting the enzyme } \\
\text { 3-hydroxy-3-methylglutaryl CoA } \\
\text { (HMG-CoA) reductase }\end{array}$ & Nonspecific, many off-target effects & $\begin{array}{c}{[54](\mathrm{p} .22)} \\
{[67,68]}\end{array}$ \\
\hline Methyl- $\beta$-cyclodextrin & CvME, Lipid raft & $\begin{array}{l}\text { Removes cholesterol out of the plasma } \\
\text { membrane by forming soluble inclusion } \\
\text { complexes with cholesterol }\end{array}$ & $\begin{array}{l}\text { Nonspecific, interferes with fluid phase } \\
\text { endocytosis and CME, might induce } \\
\text { membrane curvature }\end{array}$ & $\begin{array}{l}{[54](\text { pp. 22-23) }} \\
{[69,70]}\end{array}$ \\
\hline Nystatin & CvME, Lipid raft & Binds to cholesterol in the membrane & Toxic & [54] (pp. 23-24) \\
\hline \multicolumn{5}{|c|}{ (Endosome) acidification inhibitors } \\
\hline Monensin & $\begin{array}{c}\text { Prevents acidification of } \\
\text { endosomes }\end{array}$ & $\begin{array}{l}\text { Acts as an ionophor, thereby inhibiting } \\
\text { the acidification of endosomes }\end{array}$ & & [71-73] \\
\hline Nigericin & $\begin{array}{c}\text { Prevents acidification of } \\
\text { endosomes }\end{array}$ & $\begin{array}{l}\text { Acts as an ionophor, thereby inhibiting } \\
\text { the acidification of endosomes }\end{array}$ & & {$[74,75]$} \\
\hline Bafilomycin A1 & $\begin{array}{l}\text { Prevents acidification of } \\
\text { endosomes }\end{array}$ & $\begin{array}{l}\text { Inhibits the vacuolar ATPase endosomal } \\
\text { proton pump. }\end{array}$ & $\begin{array}{l}\text { Prevents maturation of autophagic } \\
\text { vacuoles by inhibiting fusion between } \\
\text { autophagosomes and lysosomes. } \\
\text { Potentially inhibits } \mathrm{Ca}^{2+} \text { pump SERCA }\end{array}$ & [76-78] \\
\hline Chloroquine & $\begin{array}{l}\text { Prevents acidification of } \\
\text { endosomes }\end{array}$ & $\begin{array}{l}\text { Increases } \mathrm{pH} \text { of acidic vesicles (e.g., } \\
\text { lysosomes), possibly inhibits some } \\
\text { lysosomal hydrolases }\end{array}$ & Affects many other cellular processes & $\begin{array}{c}{[79,80]} \\
(\text { pp. 49-54) }\end{array}$ \\
\hline Amiloride & Macropinocytosis & $\begin{array}{l}\text { Inhibits macropinocytosis by lowering } \\
\text { submembranous } \mathrm{pH} \text { (cytosolic } \mathrm{pH} \text { close } \\
\text { to the membrane) and prevents Rac1 and } \\
\text { Cdc42 signaling. }\end{array}$ & & [81-83] \\
\hline \multicolumn{5}{|c|}{ F-actin inhibitors } \\
\hline Cytochalasin D & Macropinocytosis & $\begin{array}{l}\text { Inhibits actin polymerization and may } \\
\text { thus lead to actin filament disassembly }\end{array}$ & $\begin{array}{l}\text { Nonspecific, may affect other endocytic } \\
\text { processes }\end{array}$ & $\begin{array}{c}{[54](p .26)} \\
{[84,85]}\end{array}$ \\
\hline Jasplakinolide & Macropinocytosis & $\begin{array}{l}\text { Stabilizes actin and promotes actin } \\
\text { assembly }\end{array}$ & $\begin{array}{l}\text { Various effects depending on cell line and } \\
\text { assay conditions }\end{array}$ & {$[84,86]$} \\
\hline
\end{tabular}


Table 1. Cont.

\begin{tabular}{|c|c|c|c|c|}
\hline Agent & Mechanism Affected ${ }^{1}$ & Effect & Limitation & Ref. \\
\hline Latrunculin & Macropinocytosis & $\begin{array}{l}\text { Sequesters actin monomers, blocks actin } \\
\text { polymerization and may thus lead to } \\
\text { actin filament disassembly }\end{array}$ & $\begin{array}{l}\text { Not necessarily efficient in adherent } \\
\text { cells }\end{array}$ & $\begin{array}{l}{[54](\mathrm{p} .26)} \\
{[87,88]}\end{array}$ \\
\hline Swinholide A & Macropinocytosis & Has F-actin severing activity & $\begin{array}{l}\text { Nonspecific, may affect other } \\
\text { endocytic processes }\end{array}$ & {$[86,89]$} \\
\hline \multicolumn{5}{|c|}{ Phosphoinositide 3-kinase inhibitors } \\
\hline LY294002 & Macropinocytosis & $\begin{array}{c}\text { Inhibits phosphatidylinositol 3-kinase } \\
\text { class I and III }\end{array}$ & $\begin{array}{c}\text { Nonspecific, also affects CME and } \\
\text { CvME }\end{array}$ & $\begin{array}{c}{[54](\text { pp. 26-27) }} \\
{[90,91]}\end{array}$ \\
\hline Wortmannin & Macropinocytosis & $\begin{array}{l}\text { Inhibits phosphatidylinositol 3-kinase } \\
\text { class I and III }\end{array}$ & $\begin{array}{l}\text { Nonspecific, also affects CME and } \\
\text { CvME }\end{array}$ & $\begin{array}{c}\text { [54] (pp. 26-27) } \\
{[90,91]}\end{array}$ \\
\hline 3-methyladenine & Macropinocytosis & $\begin{array}{l}\text { Inhibits phosphatidylinositol 3-kinase } \\
\text { class III }\end{array}$ & $\begin{array}{c}\text { Nonspecific, also affects } \mathrm{CME} \text { and } \\
\text { CvME }\end{array}$ & $\begin{array}{c}\text { [54] (pp. 26-27) } \\
\text { [92] }\end{array}$ \\
\hline
\end{tabular}

${ }^{1}$ Abbreviations: Clathrin-mediated endocytosis (CME), Caveolae-mediated endocytosis (CvME). 


\section{Uptake Mechanisms of Polymeric Micelles}

The endocytic pathways for several classes of nanoparticles have been summarized in References [25,27]. However, despite the amount of research on polymeric micelles, data regarding the uptake mechanisms and intracellular trafficking of these micelles remains behind. Furthermore, most research that investigated the endocytic uptake of polymeric micelles only analyzed the uptake of the drug, hence, only providing indirect evidence for nanocarrier uptake [47,93-101]. As will be discussed below, this assumption may not always be correct, as the carrier and the load can separate upon the uptake. To proof nanoparticle uptake, the polymer should be labelled and colocalized with the drug. Labelling of the hydrophobic polymer segment is preferable, since changes in the charge of the corona can severely alter the uptake mechanisms of the polymeric micelles compared to unlabeled polymer [49,102-104]. Table 2 gives an overview of the uptake mechanisms of different polymeric micelles in mammalian cells. A better understanding of the fate of polymeric micelles and cargo after cellular uptake might prove useful in optimizing the efficiency of the DDS. Furthermore, when the fate and intracellular trafficking of the polymeric micelles is known, various release or escape strategies could be implemented for optimal drug delivery into the cytosol. These topics have been extensively reviewed by Varkouhi et al. [105] or with a specific focus on nanoparticles by Smith et al. [36]. 
Table 2. Overview of the proposed uptake mechanisms of different polymeric micelles.

\begin{tabular}{|c|c|c|c|c|c|}
\hline Material $^{1,2}$ & Uptake Mechanism(s) $^{1}$ & Cell type ${ }^{3}$ & $\operatorname{Drug}^{1}$ & Comments & Ref. \\
\hline $\begin{array}{c}\text { Mixed micelles: } \\
\text { TPGS2K, HS15, F127 }\end{array}$ & $\begin{array}{c}\text { Energy dependent } \\
\text { CME } \\
\text { CvME }\end{array}$ & Caco-2 & $\begin{array}{l}\text { Curcumin } \\
\text { DOX }\end{array}$ & Only analyzed uptake of drug & [93] \\
\hline OCC & $\begin{array}{l}\text { CME } \\
\text { CvME }\end{array}$ & Caco-2 & $\begin{array}{c}\text { Silybin } \\
\text { Rhodamine-123 }\end{array}$ & Only analyzed uptake of drug & {$[94,95]$} \\
\hline $\begin{array}{c}\text { OGC } \\
\text { SH-OGC }\end{array}$ & $\begin{array}{l}\text { CME } \\
\text { CvME }\end{array}$ & Caco-2 & $\begin{array}{c}\text { Paclitaxel } \\
\text { Rhodamine-123 }\end{array}$ & Only analyzed uptake of drug & {$[96,97]$} \\
\hline $\mathrm{P}(\mathrm{PEGMEMA})_{75 \mathrm{u}}-\mathrm{b}-\mathrm{PMMA}_{80 \mathrm{u}}$ & $\begin{array}{c}\text { Clathrin and caveolae independent } \\
\text { CME } \\
\text { CvME }\end{array}$ & WiDr & $\begin{array}{l}\text { DOX } \\
\text { NileRed }\end{array}$ & $\begin{array}{l}80 \% \text { of the uptake was via a } \\
\text { different, undefined uptake } \\
\text { mechanism }\end{array}$ & [106] \\
\hline $\mathrm{PEG}_{2000}-\mathrm{b}-\mathrm{PLGA}_{5000}$ & $\begin{array}{l}\text { Energy dependent } \\
\text { CME }\end{array}$ & $\begin{array}{c}\text { Calu-3 } \\
\text { NCI-H441 }\end{array}$ & $\begin{array}{c}\text { NileRed } \\
\text { Curcumin acetate }\end{array}$ & Only analyzed uptake of drug & {$[98,99]$} \\
\hline $\begin{array}{c}\mathrm{PEG}_{3000 / 2000 / 5000}-\mathrm{PLA}_{40000} \\
\mathrm{PEG}_{2000 / 5000}-\mathrm{PLGA}_{40000}\end{array}$ & $\begin{array}{l}\text { Energy dependent } \\
\text { Lipid raft mediated }\end{array}$ & Caco-2 & $\begin{array}{l}\text { Curcumin } \\
\text { Coumarin } 6\end{array}$ & Only analyzed uptake of drug & {$[100]$} \\
\hline PEG $_{5000}-\mathrm{b}-\mathrm{PLA}_{5000}$ & $\begin{array}{l}\text { Direct drug transfer to cell membrane } \\
\text { Energy dependent } \\
\text { Caveolae/lipid raft-mediated endocytosis }\end{array}$ & A2780 & $\begin{array}{c}\text { Paclitaxel } \\
\text { NileRed } \\
\text { FRET, DAF/NileRed }\end{array}$ & & {$[5,107]$} \\
\hline PEG-b-PLGA & CvME & MCF-7 & $\begin{array}{l}\text { DTX, 3-MA, CQ } \\
\text { Coumarin } 6\end{array}$ & Only analyzed uptake of drug & [6] \\
\hline $\begin{array}{l}\mathrm{PEO}_{2000 / 5000 / 13000}-\mathrm{b}-\mathrm{PCL}_{5000} \\
\mathrm{PEO}_{5000}-\mathrm{b}-\mathrm{PCL}_{13000 / 24000}\end{array}$ & $\mathrm{CME}$ & MCF-7 & DiIC & $\begin{array}{l}\text { PEO5000-b-PCL13000 showed } \\
\text { fastest uptake, only analyzed } \\
\text { drug uptake }\end{array}$ & [101] \\
\hline $\begin{array}{c}\mathrm{PEO}_{2000}-\mathrm{b}-\mathrm{PCL}_{2600 / 2800} \\
\mathrm{PEO}_{5000}-\mathrm{b}-\mathrm{PCL}_{4000}\end{array}$ & Direct drug transfer to cell membrane & HCT-116 & $\begin{array}{c}\text { Pheo } \\
\text { Conjugated Fluorescein }\end{array}$ & & [108] \\
\hline $\mathrm{PEO}_{45 \mathrm{u}}-\mathrm{b}-\mathrm{PCL}_{23 \mathrm{u}}$ & $\begin{array}{c}\text { Energy dependent } \\
\text { CME }\end{array}$ & P19 & Conjugated Rhodamine & & {$[3,109]$} \\
\hline $\mathrm{PEO}_{44 \mathrm{u}}-\mathrm{b}-\mathrm{PCL}_{20 \mathrm{u}}$ & Temperature, $\mathrm{pH}$ and energy dependent & PC12 & DiIC & Only analyzed uptake of drug & [110] \\
\hline $\begin{array}{c}\mathrm{PEO}_{5000}-\mathrm{b}-\mathrm{PCL}_{2000} \\
\mathrm{PEO}_{5000}-\mathrm{b}-\mathrm{PDLLA} \\
5000\end{array}$ & Direct drug transfer to cell membrane & KB & $\begin{array}{c}\text { DiIC/DiOC } \\
\text { Conjugated Fluorescein }\end{array}$ & & [49] \\
\hline
\end{tabular}


Table 2. Cont

\begin{tabular}{|c|c|c|c|c|c|}
\hline Material $^{1,2}$ & Uptake Mechanism(s) $^{1}$ & Cell type ${ }^{3}$ & Drug $^{1}$ & Comments & Ref. \\
\hline $\mathrm{PEO}_{5000}-\mathrm{b}-\mathrm{PCL}_{4000}$ & Direct drug transfer to cell membrane & MCF-7 & $\begin{array}{c}\text { Pheo } \\
\text { DiIC/DiOC }\end{array}$ & $\begin{array}{l}\text { Micelle uptake is slow }(>4 \mathrm{hr} \text { ), } \\
\text { while release of drug is fast }\end{array}$ & {$[111$} \\
\hline 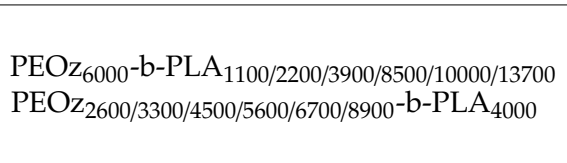 & $\begin{array}{c}\text { Energy dependent } \\
\text { Cholesterol dependent } \\
\text { Caveolae/lipid raft-mediated } \\
\text { endocytosis }\end{array}$ & MCF-7 & $\begin{array}{c}\text { Paclitaxel } \\
\text { Conjugated DEC }\end{array}$ & $\begin{array}{l}\text { PEOz/PLA ratio of 1.7-2.0 for } \\
\text { optimal uptake }\end{array}$ & [17] \\
\hline $\begin{array}{l}\text { Val-TPGS } \\
\text { Phe-TPGS }\end{array}$ & $\begin{array}{l}\text { Energy dependent } \\
\text { CvME } \\
\text { CME } \\
\text { Macropinocytosis }\end{array}$ & Caco-2 & $\begin{array}{l}\text { Curcumin } \\
\text { Coumarin } 6\end{array}$ & $\begin{array}{l}\text { Enhanced transport across } \\
\text { intestinal epithelial barrier, Only } \\
\text { analyzed uptake of drug }\end{array}$ & [47] \\
\hline
\end{tabular}

1 Abbreviations: N-octyl-O, N-carboxymethyl chitosan (OCC), N-mercapto acetyl-N'-octyl-O, N"-glycol chitosan (OGC), poly(poly(ethylene glycol) methyl ether methacrylate)(P(PEGMEMA)), poly(methyl methacrylate) (PMMA), Poly(ethylene glycol)/poly(ethylene oxide) (PEG/PEO), poly(lactide-co-glycolide) (PLGA), poly(lactide) (PLA), poly( $\varepsilon$-caprolactone) (PCL), poly((D,L-lactide) (PDLLA), poly(2-ethyl-2-oxazoline) (PEOz), D- $\alpha$-tocopheryl polyethylene glycol 1000 succinate (TPGS), Clathrin-mediated endocytosis (CME), Caveolae-mediated endocytosis (CvME), Doxorubicin (DOX), 5-dodecanoylaminofluorescein (DAF), Docetaxel (DTX), 3-methyladenine (3-MA), Chloroquine (CQ), 1,1'-Dioctadecyl-3,3,3',3'-Tetramethylindocarbocyanine Perchlorate (DiIC), Pheophorbide-a (Pheo), 3,3'-Dihexyloxacarbocyanine Iodide (DiOC), 7-N,N-diethylamino-coumarin-3 (DEC). ${ }^{2}$ When available, the average molecular weight of the polymer block is listed (Dalton). If the number of monomeric units was provided, it is denoted by a number followed by 'u.' If different sizes of the same polymer were used, they are listed separated by '\%. ${ }^{3}$ Information on the various cell lines: human colon cancer cell lines (Caco-2 and WiDr, HCT-116), human lung cancer cell lines (Calu-3 and NCI-H441), human ovarian cancer cell line (A2780), human breast cancer cell line (MCF-7), mouse pluripotent embryonic carcinoma cell line (P19), pheochromocytoma rat cell line (PC12), HeLa contaminant human tumor cell line (KB). 


\subsection{PEO-b-PCL Micelles}

Poly(ethylene oxide)-b-poly( $\left(\varepsilon\right.$-caprolactone) $\left(\mathrm{PEO}_{44 \mathrm{u}}-\mathrm{b}-\mathrm{PCL}_{20 \mathrm{u}}\right)$ micelles loaded with the fluorphore DiI were originally reported to be taken up via endocytosis, since the uptake was time, temperature, $\mathrm{pH}$ and energy dependent [110]. Uptake of conjugated rhodamine- $\mathrm{PEO}_{45 \mathrm{u}}-\mathrm{b}-\mathrm{PCL}_{23 \mathrm{u}}$ micelles in P19 cells was also shown to follow an endocytic pathway, which provided direct evidence of uptake of the whole carrier [109]. Furthermore, conjugated TMRCA-PCL $23 \mathrm{u}-\mathrm{b}-\mathrm{PEO}_{45 \mathrm{u}}$ micelles showed an increased uptake compared to the free model drug [3].

Kerdous et al. [111] has shown that pheophorbide-a (Pheo) loaded, $\mathrm{PEO}_{5000}-\mathrm{b}-\mathrm{PCL}_{4000}$ micelles did promote cellular uptake in MCF-7 cells but did not alter the subcellular distribution of Pheo when compared to the free drug. To follow the kinetics, the fluorescent signal was measured over time. This showed that the uptake of the Pheo-loaded micelles involved two processes (a fast, high intensity and slow, low intensity), while the uptake of the free drug could be described by a single rate. Förster resonance energy transfer (FRET) analysis, by incorporation of both DiI (acceptor) and DiO (donor) inside the micelles, showed that the nanocarriers as such were not effectively taken up by the cells $(4+\mathrm{h})$, suggesting separation of the load (Pheo) followed by its rapid uptake (fast process) while uptake of the nanocarriers corresponded to the slow process. The observed effect was not caused by disassembly of the micelles in media, since the nanocarriers were found to be stable in culture media, within cell cultures and in the presence of proteins.

Therefore, the uptake of the drug might be direct, via Brownian collisions between the nanocarrier and membranes (collision mechanism) or via drug diffusion through the aqueous phase (diffusion mechanism) before incorporation into the cell membrane (Figure 5A). These two proposed mechanisms are based on the theoretical model developed by Kuzelova et al. [112]. Large Unilamellar vesicles and the fluorescent sensitivity of Pheo to different environments (Figure 5B) were utilized by Kerdous et al. [111] to experimentally determine the uptake mechanism. Based on these kinetic models and experiments, it was suggested that the uptake of Pheo agrees most with the collision mechanism, in which there is direct transfer of the drug to the cell membrane.

Till et al. [108] investigated Pheo-loaded, $\mathrm{PEO}_{2000}-\mathrm{b}-\mathrm{PCL}_{2600 / 2800}$ and $\mathrm{PEO}_{5000}-\mathrm{b}-\mathrm{PCL}_{4000}$ micelle uptake in HCT-116 human colon cells and observed a similar effect as described by Kerdous et al. [111]. They suggested that the direct drug transfer might be facilitated by the PEO corona inducing dehydration of the lipid bilayer and enhancing membrane permeability $[49,111,113]$.

Interestingly, when the nanocarriers were loaded with the fluorphore DiI, instead of Pheo, direct transfer was not observed [111]. Slow uptake of DiI-loaded nanocarriers was also previously shown by Maysinger $\left(\mathrm{PEO}_{44 \mathrm{u}}-\mathrm{b}-\mathrm{PCL}_{21 \mathrm{u}}\right)$ [114] and Mahmud et al. [101] $\left(\mathrm{PEO}_{2000 / 5000 / 13000}-\mathrm{b}-\mathrm{PCL}_{5000}\right.$ and $\mathrm{PEO}_{5000}-\mathrm{b}-\mathrm{PCL}_{13000 / 24000}$ ). Pheo is less hydrophobic then DiI and might escape the nanocarrier more easily. These results show/suggest that not only the nanocarrier itself but also the drug can influence the uptake.

Therefore, Kerdous [111] and Till et al. [108] proposed that PEO-b-PCL micelles may be taken up differently depending on size and cargo. (1) Slow uptake, due to low penetration of the drug and carrier (e.g., DiI loaded), (2) drug release from carrier followed by transfer to the cell membrane (diffusion mechanism), (3) direct transfer (collision mechanism, Pheo loaded) of the drug between carrier and cell membrane.

These findings highlight the importance of not only tracing the drug but also the polymer in uptake studies. Several methods for labelling of polymeric micelles and their stability in various media were further reviewed by Savic et al. [115]. 
A-

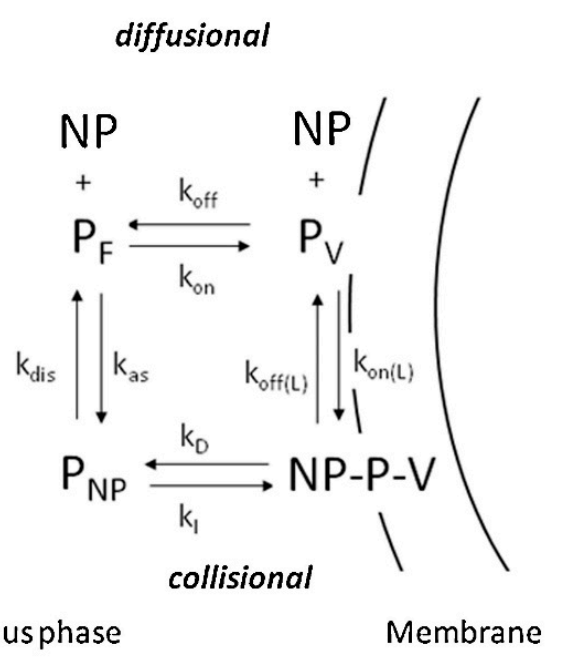

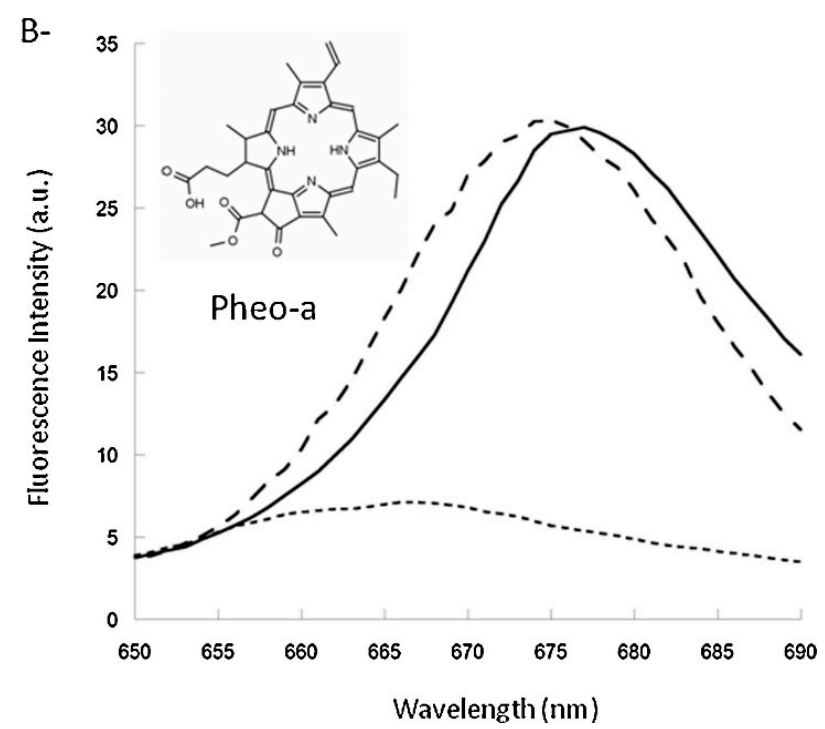

Figure 5. (A) Uptake of Pheophorbide-a (Pheo) loaded, PEO-b-PCL micelles might follow the collisional or diffusional kinetic mechanism. Which describes the free aqueous concentration of nanoparticles (NP), Pheo (PF), vesicles (V); Pheo associated to nanoparticles (PNP), vesicles (PV) and the Pheo-Nanoparticle-Vesicle complex (NP-P-V). (B) Pheo shows a different emission spectrum when present in DOPC vesicles (solid), nanoparticles (dashed) or phosphate buffered salin (PBS) (dotted), which can be used to investigate the uptake mechanisms of PEO-b-PCL micelles (reprinted from Reference [111] with permission from Elsevier).

\subsection{PEG-b-PLA}

Monodisperse poly(ethylene glycol)-b-poly(lactide) (PEG-b-PLA) micelles were already produced by Yasugi et al. [116] in 1999 with a PDI of $<0.1$ and are still being investigated as a potential DDS [117].

Chen et al. [49] investigated the uptake of DiI loaded, fluorescein labelled PEG ${ }_{5000}-\mathrm{b}-\mathrm{PDLLA}_{5000}$ polymeric micelles in KB cells. After a $24 \mathrm{~h}$ incubation, almost no uptake of the nanocarriers was observed, while the model drug was. The fluorphores DiI (acceptor) and DiO (donor) were used as a FRET pair to monitor the drug release into model membranes in real-time. The loss of FRET would be proportional to the uptake of the drug, since FRET only occurs when the fluorphores are in very close proximity to each other (below ca. $5 \mathrm{~nm}$, loaded inside the nanocarriers). The results showed that the model membrane acted as a 'sink,' facilitating an efficient transfer between the hydrophobic drug and the membrane within minutes. The same uptake was observed in mammalian KB cells (Figure 6). Once inside the cell membrane, Chen et al. [49] suggested that the drug was further internalized via endocytosis, since both sodium azide and cytochalasin D treatment inhibited further uptake. This type of direct transfer seems similar to the one observed for PEO-b-PCL micelles described above.

This drug transfer to the cell membrane was also observed by Xiao et al. [107] in the ovarian cell line A2780. PEG $_{5000}$-b-PLA 5000 micelles loaded with the fluorphore Nile red (acceptor) and labelled cell membranes with DAF (donor), were used for FRET analysis. No FRET should be observed, if the whole nanocarrier would be taken up, since the distance between the donor and acceptor would be to large (Figure 7). However, Xiao et al. [107] showed that Nile red gets effectively and quickly released into the cell membrane (within $15 \mathrm{~min}$ ). Although fusion of polymeric micelles with the cell membrane (as shown in Figure 7) cannot be directly proven with this method, supporting AFM data suggests roughening of the cell membrane upon exposure to micelles [107]. Nile red released into the membrane was further internalized using an endocytic pathway, in which lipid raft/caveolae-meditated endocytosis played a major role. 

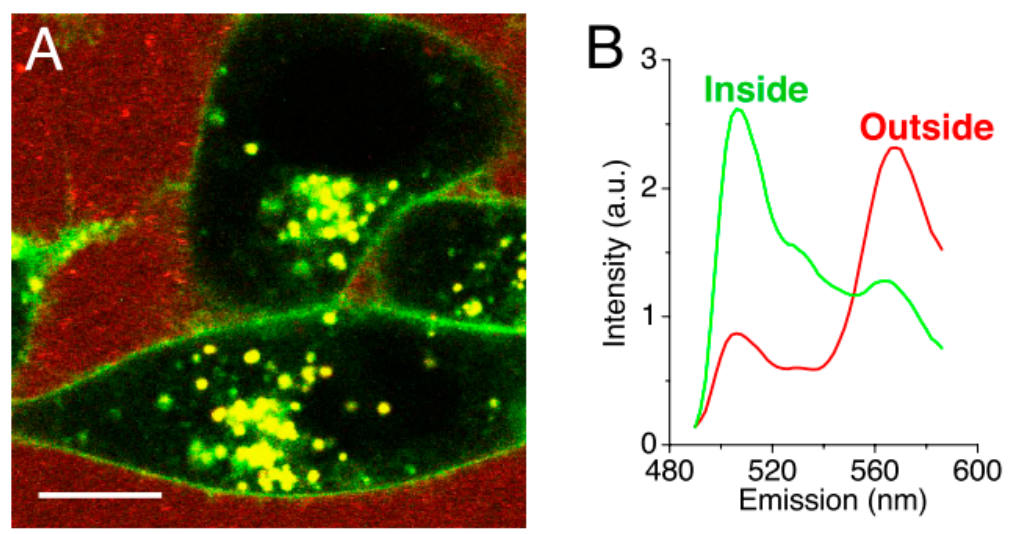

Figure 6. (A) Confocal fluorescence image of KB cells incubated with $\mathrm{DiO} / \mathrm{DiI}$ loaded micelles. The image shows the loss of Förster resonance energy transfer on the cell surface and intracellular space. (B) Normalized spectra of the measured fluorescent signal outside (red) and inside (green) the cells. (Scale bar: $10 \mu \mathrm{m}$.) (Adapted from Reference [49], Copyright 2008 National Academy of Sciences).

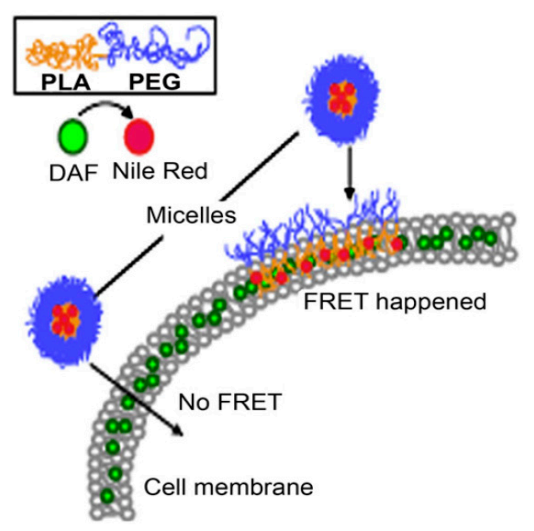

Figure 7. Förster resonance energy transfer will only occur if the micelles release their core loaded drug (Nile red, acceptor) into the DAF (donor) labelled cell membrane (Adapted from Reference [107] with permission from Elsevier).

A follow-up study further investigated this specific uptake mechanism using wild-type or dominant negative forms of proteins, since chemical inhibitors can lead to nonspecific disruption in the cell [5]. The inhibitor dynasore indicated that the uptake was dynamin dependent, which was further confirmed with a dynamin-2 negative protein. The uptake was greatly reduced when using a negative caveolin-1 protein but clathrin did not seem to be involved in the uptake. In conclusion, uptake was deemed dynamin- and caveolin-dependent but clathrin-independent, in line with [107].

The uptake of $\mathrm{PEG}_{3000}-\mathrm{PLA}_{40000}$ nanoparticles was also investigated in Caco-2 cells, however only the uptake of the drug was measured [100]. Since drug-nanocarrier separation cannot be therefore excluded, the uptake did appear to be energy-dependent, lipid raft-mediated but caveolae-independent.

While such a direct drug release into a membrane might seem beneficiary in vitro, premature release of a drug to other hydrophobic compartments in vivo could greatly reduce the DDS's efficiency. Cheng et al. [118] showed that intravenous (iv) injection of PEG-PLA micelles led to drug release and carrier breakdown within $15 \mathrm{~min}$. This breakdown was mainly caused by association of the nanocarriers with alpha and beta globulins. Sun et al. [119] also showed that 80\% of PEG-PCL/PLA micelles, upon iv injection, quickly dissociated into unimers. This effect was most likely caused by shear force and association with bloodborne proteins (particularly albumin). Therefore, the pharmacological effects of simple polymeric micelles might be limited in vivo. 


\subsection{PEG-b-PLGA}

Poly(ethylene glycol)-b-poly(lactide-co-glycolide) (PEG-b-PGLA) seems to be a promising DDS [120-122], capable of passing the blood brain barrier [123,124]. Liu et al. [125] investigated $\mathrm{PEG}_{2000} / 5000$-b-PLGA (different ratio's) micelles on their biocompatibility and indicated that all micelles presented very low cytotoxicity. $\mathrm{PEG}_{2000}-\mathrm{PLGA}_{7600}$ micelles have been conjugated successfully to doxorubicin and the micelles showed a slow, steady release of the drug (over several weeks) and enhanced uptake, compared to free doxorubicin [126]. However, literature on the specific uptake mechanisms of this DDS is rather limited.

Zhang et al. [6] observed internalization of Courmarin-6 loaded, PEG-b-PLGA (Mn 10000) micelles in MCF-7 cells after treatment of two hours. The model drug was only located in late endosomes and lysosomes, possibly indicating that the model drug bypassed early endosomes. Since this effect is also observed in caveolae-mediated endocytosis, Zhang et al. [6] suggested this as the main uptake pathway. Since only the fluorescence of the drug was measured, no conclusions about the fate of the nanocarrier can be made. The uptake of the drug/nanocarriers further induced autophagocytosis, which the same group also observed with PEG-b-PLGA nanoparticles [23].

$\mathrm{PEG}_{2000}$-b-PLGA 5000 micelles were previously created by Hu et al. [98] and the uptake in Calu-3 or NCI-H441 cells investigated [99]. After an incubation of one hour, the drug was observed in the cytosol. The uptake was deemed to be energy, cholesterol and clathrin dependent. Again, only the fluorescence of the drug was observed, which does not clearly indicate the fate of the polymeric micelles. However, the nanocarrier was loaded with both Nile red and Curcumin acetate and these could be colocalized.

\section{Conclusions}

Uptake of polymeric nanocarriers in mammalian cells is a complex process with many unknowns. Most of the reviewed studies indicate energy-dependent endocytic uptake, which can follow caveolae-, clathrin- or lipid-raft mediated pathways, as the main mechanism of internalization. As these pathways are interrelated and can be up or down regulated by a cell upon exposure to inhibitors, singling out a specific pathway is generally not possible. Interestingly, in many experiments where the loaded drug and the ABCs forming a nanocarrier were traced separately, drug-nanocarrier separation and direct drug transfer to the cell membrane were observed. While for in vitro experiments this additional mechanism can be considered as advantageous, greatly accelerating the uptake, it should be considered as indication of nanocarrier instability. Such a destabilization of nanocarriers can be particularly important in vivo, leading to opsonization, reduced circulation time, undesired drug distribution and toxicity due to incorporation of amphiphilic polymers into cell membranes. While some observations suggest that amphiphilicity or moderate hydrophobicity of the loaded drug can facilitate drug-nanocarrier separation, the factors leading to it have not yet received systematic experimental attention. Better understanding of this phenomenon and uptake mechanisms in general will lead to improved DDS with enhanced pharmaceutical efficiency and bring us one step closer to controlling the nanocarrier internalization mechanisms by design.

Author Contributions: Conceptualization, L.C.N. and L.G.; writing-original draft preparation, L.C.N.; writing-review and editing, L.G. All authors have read and agreed to the published version of the manuscript.

Funding: This research received no external funding.

Conflicts of Interest: The authors declare no conflict of interest.

\section{References}

1. Ulbrich, K.; Holá, K.; Šubr, V.; Bakandritsos, A.; Tuček, J.; Zbořil, R. Targeted Drug Delivery with Polymers and Magnetic Nanoparticles: Covalent and Noncovalent Approaches, Release Control, and Clinical Studies. Chem. Rev. 2016, 116, 5338-5431. [CrossRef] [PubMed]

2. Biswas, S.; Kumari, P.; Lakhani, P.M.; Ghosh, B. Recent advances in polymeric micelles for anti-cancer drug delivery. Eur. J. Pharm. Sci. 2016, 83, 184-202. [CrossRef] [PubMed] 
3. Savić, R.; Luo, L.; Eisenberg, A.; Maysinger, D. Micellar Nanocontainers Distribute to Defined Cytoplasmic Organelles. Science 2003, 300, 615-618. [CrossRef] [PubMed]

4. Bobo, D.; Robinson, K.J.; Islam, J.; Thurecht, K.J.; Corrie, S.R. Nanoparticle-Based Medicines: A Review of FDA-Approved Materials and Clinical Trials to Date. Pharm. Res. 2016, 33, 2373-2387. [CrossRef] [PubMed]

5. Zhang, Z.; Xiong, X.; Wan, J.; Xiao, L.; Gan, L.; Feng, Y.; Xu, H.; Yang, X. Cellular uptake and intracellular trafficking of PEG-b-PLA polymeric micelles. Biomaterials 2012, 33, 7233-7240. [CrossRef] [PubMed]

6. Zhang, X.; Zeng, X.; Liang, X.; Yang, Y.; Li, X.; Chen, H.; Huang, L.; Mei, L.; Feng, S.S. The chemotherapeutic potential of PEG-b-PLGA copolymer micelles that combine chloroquine as autophagy inhibitor and docetaxel as an anti-cancer drug. Biomaterials 2014, 35, 9144-9154. [CrossRef]

7. Cho, H.; Lai, T.C.; Tomoda, K.; Kwon, G.S. Polymeric Micelles for Multi-Drug Delivery in Cancer. AAPS PharmSciTech 2014, 16, 10-20. [CrossRef]

8. Stern, T.; Kaner, I.; Laser Zer, N.; Shoval, H.; Dror, D.; Manevitch, Z.; Chai, L.; Brill-Karniely, Y.; Benny, O. Rigidity of polymer micelles affects interactions with tumor cells. J. Control. Release 2017, 257, 40-50. [CrossRef]

9. Movassaghian, S.; Merkel, O.M.; Torchilin, V.P. Applications of polymer micelles for imaging and drug delivery. Wiley Interdiscip. Rev. Nanomed. Nanobiotechnol. 2015, 7, 691-707. [CrossRef]

10. Bareford, L.M.; Swaan, P.W. Endocytic mechanisms for targeted drug delivery. Adv. Drug Deliv. Rev. 2007, 59, 748-758. [CrossRef]

11. Torchilin, V.P. Structure and design of polymeric surfactant-based drug delivery systems. J. Control. Release 2001, 73, 137-172. [CrossRef]

12. Gothwal, A.; Khan, I.; Gupta, U. Polymeric Micelles: Recent Advancements in the Delivery of Anticancer Drugs. Pharm. Res. 2016, 33, 18-39. [CrossRef] [PubMed]

13. Alfurhood, J.A.; Sun, H.; Kabb, C.P.; Tucker, B.S.; Matthews, J.H.; Luesch, H.; Sumerlin, B.S. Poly(N-(2-hydroxypropyl)methacrylamide)-valproic acid conjugates as block copolymer nanocarriers. Polym. Chem. 2017, 8, 4983-4987. [CrossRef] [PubMed]

14. Luss, A.L.; Kulikov, P.P.; Romme, S.B.; Andersen, C.L.; Pennisi, C.P.; Docea, A.O.; Kuskov, A.N.; Velonia, K.; Mezhuev, Y.O.; Shtilman, M.I.; et al. Nanosized carriers based on amphiphilic poly-N-vinyl-2-pyrrolidone for intranuclear drug delivery. Nanomedicine 2018, 13, 703-715. [CrossRef]

15. Kulikov, P.P.; Kuskov, A.N.; Goryachaya, A.V.; Luss, A.N.; Shtil'man, M.I. Amphiphilic Poly-N-Vinyl-2-Pyrrolidone: Synthesis, Properties, Nanoparticles. Polym. Sci. Ser. D 2017, 10, 263-268. [CrossRef]

16. Glassner, M.; Vergaelen, M.; Hoogenboom, R. Poly(2-oxazoline)s: A comprehensive overview of polymer structures and their physical properties. Polym. Int. 2018, 67, 32-45. [CrossRef]

17. Wang, D.; Zhou, Y.; Li, X.; Qu, X.; Deng, Y.; Wang, Z.; He, C.; Zou, Y.; Jin, Y.; Liu, Y. Mechanisms of pH-Sensitivity and Cellular Internalization of PEOz-b-PLA Micelles with Varied Hydrophilic/Hydrophobic Ratios and Intracellular Trafficking Routes and Fate of the Copolymer. ACS Appl. Mater. Interfaces 2017, 9, 6916-6930. [CrossRef]

18. Wicki, A.; Witzigmann, D.; Balasubramanian, V.; Huwyler, J. Nanomedicine in cancer therapy: Challenges, opportunities, and clinical applications. J. Control. Release 2015, 200, 138-157. [CrossRef]

19. Maeda, H.; Bharate, G.Y.; Daruwalla, J. Polymeric drugs for efficient tumor-targeted drug delivery based on EPR-effect. Eur. J. Pharm. Biopharm. 2009, 71, 409-419. [CrossRef]

20. Li, Y.; Yu, A.; Li, L.; Zhai, G. The development of stimuli-responsive polymeric micelles for effective delivery of chemotherapeutic agents. J. Drug Target. 2018, 26, 753-765. [CrossRef]

21. Amjad, M.W.; Kesharwani, P.; Mohd Amin, M.C.I.; Iyer, A.K. Recent advances in the design, development, and targeting mechanisms of polymeric micelles for delivery of siRNA in cancer therapy. Prog. Polym. Sci. 2017, 64, 154-181. [CrossRef]

22. Kumari, A.; Yadav, S.K.S.C.; Yadav, S.K.S.C. Biodegradable polymeric nanoparticles based drug delivery systems. Colloids Surf. B. Biointerfaces 2010, 75, 1-18. [CrossRef] [PubMed]

23. Zhang, X.; Dong, Y.; Zeng, X.; Liang, X.; Li, X.; Tao, W.; Chen, H.; Jiang, Y.; Mei, L.; Feng, S.S. The effect of autophagy inhibitors on drug delivery using biodegradable polymer nanoparticles in cancer treatment. Biomaterials 2014, 35, 1932-1943. [CrossRef] [PubMed]

24. Canton, I.; Battaglia, G. Endocytosis at the nanoscale. Chem. Soc. Rev. 2012, 41, 2718-2739. [CrossRef] 
25. Behzadi, S.; Serpooshan, V.; Tao, W.; Hamaly, M.A.; Alkawareek, M.Y.; Dreaden, E.C.; Brown, D.; Alkilany, A.M.; Farokhzad, O.C.; Mahmoudi, M. Cellular uptake of nanoparticles: Journey inside the cell. Chem. Soc. Rev. 2017, 46, 4218-4244. [CrossRef]

26. Callari, M.; De Souza, P.L.; Rawal, A.; Stenzel, M.H. The Effect of Drug Loading on Micelle Properties: Solid-State NMR as a Tool to Gain Structural Insight. Angew. Chem. Int. Ed. Engl. 2017, 56, 8441-8445. [CrossRef]

27. Hillaireau, H.; Couvreur, P. Nanocarriers' entry into the cell: Relevance to drug delivery. Cell. Mol. Life Sci. 2009, 66, 2873-2896. [CrossRef]

28. Rabinovitch, M. Professional and non-professional phagocytes: An introduction. Trends Cell Biol. 1995, 5, 85-87. [CrossRef]

29. Sahay, G.; Alakhova, D.Y.; Kabanov, A.V. Endocytosis of nanomedicines. J. Control. Release 2010, 145, $182-195$. [CrossRef]

30. Champion, J.A.; Mitragotri, S. Role of target geometry in phagocytosis. Proc. Natl. Acad. Sci. USA 2006, 103, 4930-4934. [CrossRef]

31. Champion, J.A.; Katare, Y.K.; Mitragotri, S. Making polymeric micro- and nanoparticles of complex shapes. Proc. Natl. Acad. Sci. USA 2007, 104, 11901-11904. [CrossRef] [PubMed]

32. Chou, L.Y.T.; Ming, K.; Chan, W.C.W. Strategies for the intracellular delivery of nanoparticles. Chem. Soc. Rev. 2011, 40, 233-245. [CrossRef] [PubMed]

33. Roth, T.F.; Porter, K.R. Yolk Protein Uptake in the Oocyte of the Mosquito Aedes Aegypti. L. J. Cell Biol. 1964, 20, 313-332. [CrossRef] [PubMed]

34. Conner, S.D.; Schmid, S.L. Regulated portals of entry into the cell. Nature 2003, 422, 37-44. [CrossRef] [PubMed]

35. Stewart, M.P.; Lorenz, A.; Dahlman, J.; Sahay, G. Challenges in carrier-mediated intracellular delivery: Moving beyond endosomal barriers. Wiley Interdiscip. Rev. Nanomed. Nanobiotechnol. 2016, 8, 465-478. [CrossRef]

36. Smith, S.A.; Selby, L.I.; Johnston, A.P.R.; Such, G.K. The Endosomal Escape of Nanoparticles: Toward More Efficient Cellular Delivery. Bioconjug. Chem. 2019, 30, 263-272. [CrossRef]

37. Selby, L.I.; Cortez-Jugo, C.M.; Such, G.K.; Johnston, A.P.R. Nanoescapology: Progress toward understanding the endosomal escape of polymeric nanoparticles. Wiley Interdiscip. Rev. Nanomed. Nanobiotechnol. 2017, 9. [CrossRef]

38. Doherty, G.J.; McMahon, H.T. Mechanisms of Endocytosis. Annu. Rev. Biochem. 2009, 78, 857-902. [CrossRef]

39. Cole, A.J.; Yang, V.C.; David, A.E. Cancer theranostics: The rise of targeted magnetic nanoparticles. Trends Biotechnol. 2011, 29, 323-332. [CrossRef]

40. Zaki, N.M.; Tirelli, N. Gateways for the intracellular access of nanocarriers: A review of receptor-mediated endocytosis mechanisms and of strategies in receptor targeting. Expert Opin. Drug Deliv. 2010, 7, 895-913. [CrossRef]

41. Pereira, P.; Pedrosa, S.S.; Wymant, J.M.; Sayers, E.; Correia, A.; Vilanova, M.; Jones, A.T.; Gama, F.M. SiRNA inhibition of endocytic pathways to characterize the cellular uptake mechanisms of folate-functionalized glycol chitosan nanogels. Mol. Pharm. 2015, 12, 1970-1979. [CrossRef] [PubMed]

42. Al Soraj, M.; He, L.; Peynshaert, K.; Cousaert, J.; Vercauteren, D.; Braeckmans, K.; De Smedt, S.C.; Jones, A.T. siRNA and pharmacological inhibition of endocytic pathways to characterize the differential role of macropinocytosis and the actin cytoskeleton on cellular uptake of dextran and cationic cell penetrating peptides octaarginine (R8) and HIV-Tat. J. Control. Release 2012, 161, 132-141. [CrossRef] [PubMed]

43. Glebov, O.O.; Bright, N.A.; Nichols, B.J. Flotillin-1 defines a clathrin-independent endocytic pathway in mammalian cells. Nat. Cell Biol. 2006, 8, 46-54. [CrossRef] [PubMed]

44. Zhao, J.; Stenzel, M.H. Entry of nanoparticles into cells: The importance of nanoparticle properties. Polym. Chem. 2018, 9, 259-272. [CrossRef]

45. Iversen, T.G.; Skotland, T.; Sandvig, K. Endocytosis and intracellular transport of nanoparticles: Present knowledge and need for future studies. Nano Today 2011, 6, 176-185. [CrossRef]

46. Dutta, D.; Donaldson, J.G. Search for inhibitors of endocytosis. Cell. Logist. 2013, 2, 203-208. [CrossRef]

47. Wang, J.; Wang, L.; Li, Y.; Wang, X.; Tu, P. Apically targeted oral micelles exhibit highly efficient intestinal uptake and oral absorption. Int. J. Nanomed. 2018, 13, 7997-8012. [CrossRef] 
48. Ghetler, Y.; Yavin, S.; Shalgi, R.; Arav, A. The effect of chilling on membrane lipid phase transition in human oocytes and zygotes. Hum. Reprod. 2005, 20, 3385-3389. [CrossRef]

49. Chen, H.; Kim, S.; Li, L.; Wang, S.; Park, K.; Cheng, J.-X. Release of hydrophobic molecules from polymer micelles into cell membranes revealed by Forster resonance energy transfer imaging. Proc. Natl. Acad. Sci. USA 2008, 105, 6596-6601. [CrossRef]

50. Mann, S.K.; Czuba, E.; Selby, L.I.; Such, G.K.; Johnston, A.P.R. Quantifying Nanoparticle Internalization Using a High Throughput Internalization Assay. Pharm. Res. 2016, 33, 2421-2432. [CrossRef]

51. Vercauteren, D.; Vandenbroucke, R.E.; Jones, A.T.; Rejman, J.; Demeester, J.; De Smedt, S.C.; Sanders, N.N.; Braeckmans, $\mathrm{K}$. The use of inhibitors to study endocytic pathways of gene carriers: Optimization and pitfalls. Mol. Ther. 2010, 18, 561-569. [CrossRef] [PubMed]

52. Götte, M.; Sofeu Feugaing, D.D.; Kresse, H. Biglycan is internalized via a chlorpromazine-sensitive route. Cell. Mol. Biol. Lett. 2004, 9, 475-481. [PubMed]

53. Wang, L.-H.; Rothberg, K.G.; Anderson, R.G.W. Mis-Assembly of Clathrin Lattices on Endosomes Reveals a Regulatory Switch for Coated Pit Formation. J. Cell Biol. 1993, 123, 1107-1117. [CrossRef] [PubMed]

54. Ivanov, A.I. Pharmacological Inhibition of Endocytic Pathways: Is It Specific Enough to Be Useful? In Exocytosis and Endocytosis; Ivanov, A.I., Ed.; Humana Press: Totowa, NJ, USA, 2008; ISBN 978-1-59745-178-9.

55. Qaddoumi, M.G.; Gukasyan, H.J.; Lee, V.H.L.; Davda, J.; Labhasetwar, V.; Kim, K.-J. Clathrin and caveolin-1 expression in primary pigmented rabbit conjunctival epithelial cells: Role in PLGA nanoparticle endocytosis. Mol. Vis. 2003, 9, 559-568.

56. Carpentier, J.-L.; Sawano, F.; Geiger, D.; Gorden, P.; Perrelet, A.; Orci, L. Potassium depletion and hypertonic medium reduce "non-coated" and clathrin-coated pit formation, as well as endocytosis through these two gates. J. Cell. Physiol. 1989, 138, 519-526. [CrossRef]

57. Gibson, A.E.; Noel, R.J.; Herlihy, J.T.; Ward, W.F. Phenylarsine oxide inhibition of endocytosis: Effects on asialofetuin internalization. Am. J. Physiol. Physiol. 2017, 257, C182-C184. [CrossRef]

58. Huang, P.; Zhang, Y.H.; Zheng, X.W.; Liu, Y.J.; Zhang, H.; Fang, L.; Zhang, Y.W.; Yang, C.; Islam, K.; Wang, C.; et al. Phenylarsine oxide (PAO) induces apoptosis in HepG2 cells: Via ROS-mediated mitochondria and ER-stress dependent signaling pathways. Metallomics 2017, 9, 1756-1764. [CrossRef]

59. Altankov, G.; Grinnell, F. Depletion of intracellular potassium disrupts coated pits and reversibly inhibits cell polarization during fibroblast spreading. J. Cell Biol. 1993, 120, 1449-1459. [CrossRef]

60. Preta, G.; Cronin, J.G.; Sheldon, I.M. Dynasore-Not just a dynamin inhibitor. Cell Commun. Signal. 2015, 13, 24. [CrossRef]

61. Kirchhausen, T.; Macia, E.; Pelish, H.E. Use of Dynasore, the Small Molecule Inhibitor of Dynamin, in the Regulation of Endocytosis. Methods Enzym. 2008, 438, 77-93.

62. Pelkmans, L.; Püntener, D.; Helenius, A. Local actin polymerization and dynamin recruitment in SV40-induced internalization of caveolae. Science 2002, 296, 535-539. [CrossRef] [PubMed]

63. Costa Verdera, H.; Gitz-Francois, J.J.; Schiffelers, R.M.; Vader, P. Cellular uptake of extracellular vesicles is mediated by clathrin-independent endocytosis and macropinocytosis. J. Control. Release 2017, 266, 100-108. [CrossRef] [PubMed]

64. Parton, R.G.; Joggerst, B.; Simons, K. Regulated internalization of caveolae. J. Cell Biol. 1994, 127, $1199-1215$. [CrossRef] [PubMed]

65. Milhaud, J. Permeabilizing action of filipin III on model membranes through a filipin-phospholipid binding. BBA Biomembranes 1992, 1105, 307-318. [CrossRef]

66. Song, X.; Li, R.; Deng, H.; Li, Y.; Cui, Y.; Zhang, H.; Dai, W.; He, B.; Zheng, Y.; Wang, X.; et al. Receptor mediated transcytosis in biological barrier: The influence of receptor character and their ligand density on the transmembrane pathway of active-targeting nanocarriers. Biomaterials 2018, 180, 78-90. [CrossRef]

67. Sidaway, J.E.; Davidson, R.G.; McTaggart, F.; Orton, T.C.; Scott, R.C.; Smith, G.J.; Brunskill, N.J. Inhibitors of 3-hydroxy-3-methylglutaryl-CoA reductase reduce receptor-mediated endocytosis in opossum kidney cells. J. Am. Soc. Nephrol. 2004, 15, 2258-2265. [CrossRef]

68. Loike, J.D.; Shabtai, D.Y.; Neuhut, R.; Malitzky, S.; Lu, E.; Husemann, J.; Goldberg, I.J.; Silverstein, S.C. Statin inhibition of Fc receptor-mediated phagocytosis by macrophages is modulated by cell activation and cholesterol. Arter. Thromb. Vasc. Biol. 2004, 24, 2051-2056. [CrossRef] 
69. Rodal, S.K.; Skretting, G.; Garred, Ø.; Vilhardt, F.; Van Deurs, B.; Sandvig, K. Extraction of Cholesterol with Methyl-b-Cyclodextrin Perturbs Formation of Clathrin-coated Endocytic Vesicles. 1999, 10, 961-974. Mol. Biol. Cell 1999, 10, 961-974. [CrossRef]

70. Hirama, T.; Fairn, G.D. Induction of spontaneous curvature and endocytosis: Unwanted consequences of cholesterol extraction using methyl- $\beta$-Cyclodextrin. Commun. Integr. Biol. 2018, 11, 1-4. [CrossRef]

71. Hedin, U.; Thyberg, J. Receptor-mediated endocytosis of immunoglobulin-coated colloidal gold particles in cultured mouse peritoneal macrophages. Chloroquine and monensin inhibit transfer of the ligand from endocytic vesicles to lysosomes. Eur. J. Cell Biol. 1985, 39, 130-135.

72. Veldhoen, S.; Laufer, S.D.; Trampe, A.; Restle, T. Cellular delivery of small interfering RNA by a non-covalently attached cell-penetrating peptide: Quantitative analysis of uptake and biological effect. Nucleic Acids Res. 2006, 34, 6561-6573. [CrossRef] [PubMed]

73. Heo, C.H.; Cho, M.K.; Shin, S.; Yoo, T.H.; Kim, H.M. Real-time monitoring of vesicle pH in an endocytic pathway using an EGF-conjugated two-photon probe. Chem. Commun. 2016, 52, 14007-14010. [CrossRef]

74. Oishi, M.; Kataoka, K.; Nagasaki, Y. pH-responsive three-layered PEGylated polyplex micelle based on a lactosylated $\mathrm{ABC}$ triblock copolymer as a targetable and endosome-disruptive nonviral gene vector. Bioconjug. Chem. 2006, 17, 677-688. [CrossRef] [PubMed]

75. Uherek, C.; Fominaya, J.; Wels, W. A Modular DNA Carrier Protein Based on the Structure of Diphtheria Toxin Mediates Target Cell-specific Gene Delivery. J. Biol. Chem. 1998, 273, 8835-8841. [CrossRef] [PubMed]

76. Issa, M.M.; Köping-Höggård, M.; Tømmeraas, K.; Vårum, K.M.; Christensen, B.E.; Strand, S.P.; Artursson, P. Targeted gene delivery with trisaccharide-substituted chitosan oligomers in vitro and after lung administration in vivo. J. Control. Release 2006, 115, 103-112. [CrossRef] [PubMed]

77. Yamamoto, A.; Tagawa, Y.; Yoshimori, T.; Moriyama, Y.; Masaki, R.; Tashiro, Y. Bafilomycin A1 Prevents Maturation of Autophagic Vacuoles by Inhibiting Fusion between Autophagosomes and Lysosomes in Rat Hepatoma Cell Line, H-4-II-E Cells. Cell Struct. Funct. 1998, 23, 33-42. [CrossRef]

78. Mauvezin, C.; Nagy, P.; Juhász, G.; Neufeld, T.P. Autophagosome-lysosome fusion is independent of V-ATPase-mediated acidification. Nat. Commun. 2015, 6, 7007. [CrossRef]

79. Dijkstra, J.; van Galen, M.; Scherphof, G.L. Effects of Ammonium Chloride and Chloroquine on Endocytic Uptake of Liposomes by Kupffer Cells in Vitro. BBA Mol. Cell Res. 1984, 804, 58-67. [CrossRef]

80. Browning, D.J. Hydroxychloroquine and Chloroquine Retinopathy; Springer: New York, NY, USA, 2014; ISBN 9781493905973.

81. Kerr, M.C.; Teasdale, R.D. Defining macropinocytosis. Traffic 2009, 10, 364-371. [CrossRef]

82. Koivusalo, M.; Welch, C.; Hayashi, H.; Scott, C.C.; Kim, M.; Alexander, T.; Touret, N.; Hahn, K.M.; Grinstein, S. Amiloride inhibits macropinocytosis by lowering submembranous $\mathrm{pH}$ and preventing Rac1 and Cdc42 signaling. J. Cell Biol. 2010, 188, 547-563. [CrossRef]

83. Bhattarai, N.; Mathis, J.M.; Chen, M.; Pérez, R.L.; Siraj, N.; Magut, P.K.S.; McDonough, K.; Sahasrabudhe, G.; Warner, I.M. Endocytic Selective Toxicity of Rhodamine 6G nanoGUMBOS in Breast Cancer Cells. Mol. Pharm. 2018, 15, 3837-3845. [CrossRef] [PubMed]

84. Fujimoto, L.M.; Roth, R.; Heuser, J.E.; Schmid, S.L. Actin Assembly Plays a Variable, but not Obligatory Role in Receptor-Mediated Endocytosis. Traffic 2000, 1, 161-171. [CrossRef] [PubMed]

85. Dong, F.; Dong, X.; Zhou, L.; Xiao, H.; Ho, P.Y.; Wong, M.S.; Wang, Y. Doxorubicin-loaded biodegradable self-assembly zein nanoparticle and its anti-cancer effect: Preparation, in vitro evaluation, and cellular uptake. Colloids Surf. B Biointerfaces 2016, 140, 324-331. [CrossRef] [PubMed]

86. Fenteany, G.; Zhu, S. Small-Molecule Inhibitors of Actin Dynamics and Cell Motility. Curr. Top. Med. Chem. 2003, 3, 593-616. [CrossRef]

87. Wakatsuki, T.; Schwab, B.; Thompson, N.C.; Elson, E.L. Effects of cytochalasin D and latrunculin B on mechanical properties of cells. J. Cell Sci. 2000, 114, 1025-1036.

88. Yarmola, E.G.; Somasundaram, T.; Boring, T.A.; Spector, I.; Bubb, M.R. Actin-latrunculin a structure and function: Differential modulation of actin-binding protein function by latrunculin A. J. Biol. Chem. 2000, 275, 28120-28127. [CrossRef]

89. Bubb, M.R.; Spector, I.; Bershadsky, A.D.; Korn, E.D. Swinholide A is a microfilament disrupting marine toxin that stabilizes actin dimers and severs actin filaments. J. Biol. Chem. 1995, 270, 3463-3466. [CrossRef]

90. Corvera, S.; Czech, M.P. Direct targets of phosphoinositide 3-kinase products in membrane traffic and signal transduction. Trends Cell Biol. 1998, 8, 442-446. [CrossRef] 
91. Jess, T.J.; Thomson, F.J.; Gould, G.W.; Belham, C.M.; Scott, P.H.; Plevin, R.J. Phosphatidylinositol 3'-kinase, but not p70 ribosomal S6 kinase, is involved in membrane protein recycling: Wortmannin inhibits glucose transport and downregulates cell-surface transferrin receptor numbers independently of any effect on fluid-phase endocy. Cell. Signal. 1996, 8, 297-304. [CrossRef]

92. Araki, N.; Hamasaki, M.; Egami, Y.; Hatae, T. Effect of 3-methyladenine on the Fusion Process of Macropinosomes in EGF-stimulated A431 Cells. Cell Struct. Funct. 2006, 31, 145-157. [CrossRef]

93. Wang, J.; Ma, W.; Tu, P. The mechanism of self-assembled mixed micelles in improving curcumin oral absorption: In vitro and in vivo. Colloids Surf. B Biointerfaces 2015, 133, 108-119. [CrossRef] [PubMed]

94. Yin, T.; Zhang, Y.; Liu, Y.; Chen, Q.; Fu, Y.; Liang, J.; Zhou, J.; Tang, X.; Liu, J.; Huo, M. The efficiency and mechanism of N-octyl-O, N-carboxymethyl chitosan-based micelles to enhance the oral absorption of silybin. Int. J. Pharm. 2018, 536, 231-240. [CrossRef] [PubMed]

95. Huo, M.; Zhang, Y.; Zhou, J.; Zou, A.; Li, J. Formation, microstructure, biodistribution and absence of toxicity of polymeric micelles formed by N-octyl-N,O-carboxymethyl chitosan. Carbohydr. Polym. 2011, 83, 1959-1969. [CrossRef]

96. Huo, M.; Fu, Y.; Liu, Y.; Chen, Q.; Mu, Y.; Zhou, J.; Li, L.; Xu, W.; Yin, T. N-mercapto acetyl-N'-octyl-O, N"-glycol chitosan as an efficiency oral delivery system of paclitaxel. Carbohydr. Polym. 2018, 181, 477-488. [CrossRef] [PubMed]

97. Huo, M.; Zhang, Y.; Zhou, J.; Zou, A.; Yu, D.; Wu, Y.; Li, J.; Li, H. Synthesis and characterization of low-toxic amphiphilic chitosan derivatives and their application as micelle carrier for antitumor drug. Int. J. Pharm. 2010, 394, 162-173. [CrossRef]

98. Hu, X.; Yang, F.F.; Quan, L.H.; Liu, C.Y.; Liu, X.M.; Ehrhardt, C.; Liao, Y.H. Pulmonary delivered polymeric micelles-Pharmacokinetic evaluation and biodistribution studies. Eur. J. Pharm. Biopharm. 2014, 88, 1064-1075. [CrossRef]

99. Hu, X.; Yang, F.F.; Liu, C.Y.; Ehrhardt, C.; Liao, Y.H. In vitro uptake and transport studies of PEG-PLGA polymeric micelles in respiratory epithelial cells. Eur. J. Pharm. Biopharm. 2017, 114, 29-37. [CrossRef]

100. Song, Q.; Wang, X.; Hu, Q.; Huang, M.; Yao, L.; Qi, H.; Qiu, Y.; Jiang, X.; Chen, J.; Chen, H.; et al. Cellular internalization pathway and transcellular transport of pegylated polyester nanoparticles in Caco-2 cells. Int. J. Pharm. 2013, 445, 58-68. [CrossRef]

101. Mahmud, A.; Lavasanifar, A. The effect of block copolymer structure on the internalization of polymeric micelles by human breast cancer cells. Colloids Surf. B Biointerfaces 2005, 45, 82-89. [CrossRef]

102. Fröhlich, E. The role of surface charge in cellular uptake and cytotoxicity of medical nanoparticles. Int. J. Nanomed. 2012, 7, 5577-5591. [CrossRef]

103. Zhou, D.H.; Zhang, J.; Zhang, G.; Gan, Z.H. Effect of surface charge of polymeric micelles on in vitro cellular uptake. Chin. J. Polym. Sci. (Engl. Ed.) 2013, 31, 1299-1309. [CrossRef]

104. Moghimi, S.M.; Hunter, A.C.; Murray, J.C.; Szewczyk, A. Cellular Distribution of Nonionic Micelles. Science 2004, 303, 626-628. [CrossRef] [PubMed]

105. Varkouhi, A.K.; Scholte, M.; Storm, G.; Haisma, H.J. Endosomal escape pathways for delivery of biologicals. J. Control. Release 2011, 151, 220-228. [CrossRef]

106. Chang, T.; Gosain, P.; Stenzel, M.H.; Lord, M.S. Drug-loading of poly(ethylene glycol methyl ether methacrylate) (PEGMEMA)-based micelles and mechanisms of uptake in colon carcinoma cells. Colloids Surf. $B$ Biointerfaces 2016, 144, 257-264. [CrossRef] [PubMed]

107. Xiao, L.; Xiong, X.; Sun, X.; Zhu, Y.; Yang, H.; Chen, H.; Gan, L.; Xu, H.; Yang, X. Role of cellular uptake in the reversal of multidrug resistance by PEG-b-PLA polymeric micelles. Biomaterials 2011, 32, 5148-5157. [CrossRef]

108. Till, U.; Gibot, L.; Mingotaud, A.F.; Ehrhart, J.; Wasungu, L.; Mingotaud, C.; Souchard, J.P.; Poinso, A.; Rols, M.P.; Violleau, F.; et al. Drug release by direct jump from poly(ethylene-glycol-b- $\epsilon$-caprolactone) nano-vector to cell membrane. Molecules 2016, 21, 1643. [CrossRef] [PubMed]

109. Luo, L.; Tam, J.; Maysinger, D.; Eisenberg, A. Cellular internalization of poly(ethylene oxide)-b-poly( $\varepsilon$-caprolactone) diblock copolymer micelles. Bioconjug. Chem. 2002, 13, 1259-1265. [CrossRef]

110. Allen, C.; Yu, Y.; Eisenberg, A.; Maysinger, D. Cellular internalization of PCL20-b-PEO44block copolymer micelles. Biochim. Biophys. Acta Biomembr. 1999, 1421, 32-38. [CrossRef]

111. Kerdous, R.; Sureau, F.; Bour, A.; Bonneau, S. Release kinetics of an amphiphilic photosensitizer by block-polymer nanoparticles. Int. J. Pharm. 2015, 495, 750-760. [CrossRef] 
112. Kuzelova, K.; Brault, D. Kinetic and equilibrium studies of porphyrin interactions with unilamellar lipidic vesicles. Biochemistry 1994, 33, 9447-9459. [CrossRef]

113. Aldwinckle, T.J.; Ahkong, Q.F.; Bangham, A.D.; Fisher, D.; Lucy, J.A. Effects of poly(ethylene glycol) on liposomes and erythrocytes: Permeability changes and membrane fusion. Biochim. Biophys. Acta Biomembr. 1982, 689, 548-560. [CrossRef]

114. Maysinger, D.; Berezovska, O.; Savic, R.; Lim Soo, P.; Eisenberg, A. Block copolymers modify the internalization of micelle-incorporated probes into neural cells. Biochim. Biophys. Acta Mol. Cell Res. 2001, 1539, 205-217. [CrossRef]

115. Savić, R.; Azzam, T.; Eisenberg, A.; Maysinger, D. Assessment of the integrity of poly(caprolactone)b-poly(ethylene oxide) micelles under biological conditions: A fluorogenic-based approach. Langmuir 2006, 22, 3570-3578. [CrossRef] [PubMed]

116. Yasugi, K.; Nagasaki, Y.; Kato, M.; Kataoka, K. Preparation and characterization of polymer micelles from poly(ethylene glycol)-poly(D,L-lactide) block copolymers as potential drug carrier. J. Control. Release 1999, 62, 89-100. [CrossRef]

117. Xiao, L.; Huang, L.; Moingeon, F.; Gauthier, M.; Yang, G. PH-Responsive Poly(Ethylene Glycol)-block-Polylactide Micelles for Tumor-Targeted Drug Delivery. Biomacromolecules 2017, 18, 2711-2722. [CrossRef] [PubMed]

118. He, W.; Cheng, J.-X.; Kim, S.; Low, P.S.; Wang, H.; Chen, H.; Park, K. Fast Release of Lipophilic Agents from Circulating PEG-PDLLA Micelles Revealed by in Vivo Förster Resonance Energy Transfer Imaging. Langmuir 2008, 24, 5213-5217.

119. Sun, X.; Wang, G.; Zhang, H.; Hu, S.; Liu, X.; Tang, J.; Shen, Y. The Blood Clearance Kinetics and Pathway of Polymeric Micelles in Cancer Drug Delivery. ACS Nano 2018, 12, 6179-6192. [CrossRef]

120. Babos, G.; Biró, E.; Meiczinger, M.; Feczkó, T. Dual Drug Delivery of Sorafenib and Doxorubicin from PLGA and PEG-PLGA Polymeric Nanoparticles. Polymers 2018, 10, 895. [CrossRef]

121. Rompicharla, S.V.K.; Trivedi, P.; Kumari, P.; Muddineti, O.S.; Theegalapalli, S.; Ghosh, B.; Biswas, S. Evaluation of Anti-Tumor Efficacy of Vorinostat Encapsulated Self-Assembled Polymeric Micelles in Solid Tumors. AAPS PharmSciTech 2018, 19, 3141-3151. [CrossRef]

122. Xie, Y.; Liu, C.; Huang, H.; Huang, J.; Deng, A.; Zou, P.; Tan, X. Bone-targeted delivery of simvastatin-loaded PEG-PLGA micelles conjugated with tetracycline for osteoporosis treatment. Drug Deliv. Transl. Res. 2018, 8 , 1090-1102. [CrossRef]

123. Sánchez-López, E.; Ettcheto, M.; Egea, M.A.; Espina, M.; Cano, A.; Calpena, A.C.; Camins, A.; Carmona, N.; Silva, A.M.; Souto, E.B.; et al. Memantine loaded PLGA PEGylated nanoparticles for Alzheimer's disease: In vitro and in vivo characterization. J. Nanobiotechnol. 2018, 16, 1-16. [CrossRef] [PubMed]

124. Abourehab, M.A.S.; Ahmed, O.A.A.; Balata, G.F.; Almalki, W.H. Self-assembled biodegradable polymeric micelles to improve dapoxetine delivery across the blood-brain barrier. Int. J. Nanomed. 2018, 13, 3679-3687. [CrossRef] [PubMed]

125. Liu, X.; Shen, X.; Sun, X.; Peng, Y.; Li, R.; Yun, P.; Li, C.; Liu, L.; Su, F.; Li, S. Biocompatibility evaluation of self-assembled micelles prepared from poly(lactide-co-glycolide)-poly(ethylene glycol) diblock copolymers. Polym. Adv. Technol. 2018, 29, 205-215. [CrossRef]

126. Yoo, H.S.; Park, T.G. Biodegradable polymeric micelles composed of doxorubicin conjugated PLGA-PEG block copolymer. J. Control. Release 2001, 70, 63-70. [CrossRef]

(C) 2020 by the authors. Licensee MDPI, Basel, Switzerland. This article is an open access article distributed under the terms and conditions of the Creative Commons Attribution (CC BY) license (http://creativecommons.org/licenses/by/4.0/). 